\title{
PENGARUH CAMPURAN BAHAN BAKAR PERTAMAX DENGAN METHANOL (BLENDING) TERHADAP PERFORMA MESIN DAN EMISI GAS BUANG PADA MOTOR HONDA MEGAPRO 160 CC TAHUN 2008
}

\author{
Rofiqul Khuluq \\ Teknik Mesin, Fakultas Teknik \\ Universitas Maarif Hasyim Latif, Sidoarjo, Indonesia \\ e-mail : rofiqul-khuluq@student.umaha.ac.id
}

\begin{abstract}
ABSTRAK
Pada saat ini pemakaian motor menggunakan bahan bakar minyak fosil semakin meningkat pesat, Minyak fosil adalah salah satu bahan bakar fosil yang sering di gunakan dalam sehari-hari seperti banyak di gunakan di bahan bakar sepeda motor, mobil, begitu pula di dunia industri juga memerlukan bahan bakar minyak bumi, kurangnya pemenuhan akan energi berpengaruh terhadap aktifitas untuk menjalankan berbagai kegiatan seperti transportasi, mesin industri apabila penggunaan bahan bakar minyak bumi di Indonesia maka di perlukan suatu bahan bakar alternatif dari bahan bakar hayati yaitu methanol yang berjenis spiritus, bahan bakar alternatif methanol ini menjadi pilihan atau solusi untuk mengurangi ketergantungan pada pemakaian bahan bakar minyak bumi, hal ini mengkhawatirkan cadangan minyak bumi cenderung berkurang karena digunakan dalam sehari-hari selalu membutuhkan bagi kebutuhan manusia, semakin menipisnya saya tertarik untuk meneliti campuran pertamax dengan methanol (blending-B). Metodologi penelitian ini dilakukan secara exsperimental pada motor Honda Megapro $160 \mathrm{cc}$ tahun 2008 dengan bahan bakar B100, B70, B60 dan B50 di kampus UNESA ketintang dan SMK PGRI 1 Sidoarjo untuk mengetahui pengaruh terhadap torsi, daya, konsumsi bahan bakar dan sisa gas pembuangan. Hasil dari pengujian ini menunjukan nilai tertinggi torsi 7,31 Nm pada campuran B60 putaran $9532 \mathrm{rpm}$, daya11,2 HP pada B60 putaran 12891 rpm, konsumsi bahan bakar paling hemat B50 pada putaran 12652 rpm, daya 11,5 HP dibandingkan B100, B70 dan B60, sedangkan pengujian sisa hasil pembakaran yang paling ramah lingkungan pada B70 dengan kadar CO 6,95 \%vol dan HC 1314,6 ppmvol.
\end{abstract}

Kata kunci: blending, methanol, perfoma mesin, pertamax

\section{PENDAHULUAN}

\subsection{Latar Belakang}

Pada saat ini pemakaian motor menggunakan bahan bakar fosil dari hari ke tahun semakin meningkat cepat, hal ini mengakibatkan penggunaan bahan bakar fosil semakin membludak dan tentu sangat mengkhawatirkan karena dengan membludak penggunaan bahan bakar fosil maka cadangan akan semakin berkurang sedangkan kebutuhan akan minyak hasil bumi semakin terus bertambah pesat, minyak bumi merupakan salah satu bahan bakar fosil yang sering di gunakan dalam sehari-hari, kurangnya pemenuhan akan energi berpengaruh terhadap aktifitas untuk menjalankan berbagai kegiatan seperti transportasi.

Methanol adalah sebuah zat yang bisa dijadikan bahan bakar pada mesin pembakaran dalam dengan angka oktannya 105, sebagai senyawa methanol pada suhu 150c dapat dicampurkan dengan bahan bakar fosil yang disebut bioalkhol mampu menghasilkan suhu yang besar yang tidak dapat melewati $15 \%$, hal ini dikarenakan methanol bersifat polar sehingga kelarutan methanol rendah dalam senyawa alkane,
Penggunaan metanol sebagai bahan bakar langsung hanya bisa dilakukan pada mesin khusus atau melakukan modifikasi pada mesin berbahan bakar bensin. Hal ini dilakukan karena metanol bersifat korosif. Untuk mengatasi hal ini maka dilakukan pencampuran metanol kedalam bahan bakar pertamax dengan kadar tertentu.

\subsection{Rumusan masalah}

Adapun perumusan masalah dari analisa dan penulisan ini yaitu :

1. Berapa perbandingan torsi maksimum yang dihasilkan sepeda motor Honda megapro $160 \mathrm{cc}$ tahun 2008, dengan variasi (Blending-B) bahan bakar pertamax dan methanol B100, B70, B60, B50.

2. Berapa perbandingan daya maksimum yang dihasilkan sepeda motor Honda megapro $160 \mathrm{cc}$ tahun 2008, dengan variasi (Blending-B) bahan bakar pertamax dan methanol B100, B70, B60, B50.

3. Berapa perbandingan konsumsi bahan bakar rata - rata yang diperlukan sepeda motor Honda megapro 160cc tahun 2008, dengan 
variasi (Blending-B) bahan bakar pertamax dan methanol B100, B70, B60, B50.

4. Berapa perbandingan emisi gas buang rata rata yang diperlukan sepeda motor Honda megapro 160cc tahun 2008, dengan variasi (Blending-B) bahan bakar pertamax dan methanol B100, B70, B60, B50.

5. Variasi campuran manakah yang menghasilkan unjuk kerja paling baik terhadap sepeda motor Honda megapro 160cc tahun 2008.

\subsection{Batasan masalah}

Adapun batasan masalah dari analisa dan penulisan ini yaitu :

1. Objek penelitian menggunakan sepeda motor Honda megapro 160cc tahun 2008.

2. Variasi (Blending-B) bahan bakar pertamax dan methanol B100, B70, B60, B50.

3. Data yang dianalisa dalam pengujian adalah daya mesin, torsi, konsumsi bahan bakar dan gas sisa pembuangan.

\subsection{Tujuan}

Adapun tujuan masalah dari analisa dan penulisan ini yaitu :

1. Mengetahui perbandingan torsi maksimum yang dihasilkan sepeda motor Honda megapro 160 cc tahun 2008, dengan variasi (Blending-B) bahan bakar pertamax dan methanol B100, B70, B60, B50.

2. Mengetahui perbandingan daya maksimum yang dihasilkan sepeda motor Honda megapro 160 cc tahun 2008, dengan variasi (Blending-B) bahan bakar pertamax dan methanol B100, B70, B60, B50.

3. Mengetahui perbandingan konsumsi bahan bakar rata - rata yang diperlukan sepeda motor Honda megapro 160cc tahun 2008, dengan variasi (Blending-B) bahan bakar pertamax dan methanol B100, B70, B60, B50.

4. Mengetahui perbandingan emisi gas buang rata - rata yang diperlukan sepeda motor Honda megapro 160cc tahun 2008, dengan variasi (Blending-B) bahan bakar pertamax dan methanol B100, B70, B60, B50.

5. Variasi campuran manakah yang menghasilkan unjuk kerja paling baik terhadap sepeda motor Honda megapro 160cc tahun 2008.

\subsection{Manfaat}

Adapun manfaat dari analisa dan penulisan ini yaitu :

1. Bagi ilmu pengetahuan

Memberikan informasi terhadap energi baru khususnya minyak bumi sebagai pengalihan dari bahan bakar fosil ke campuran bahan bakar.
2. Bagi lembaga akademik

Kususnya bagi Universitas Maarif Hasyim latif sebagai lembaga pendidikan formal yang dapat membantu memperkenalkan terhadap masyarakat.

3. Supaya dapat di jadikan informasi \& dapat di kembangkan lagi bagi mahasiswa dalam penyusunan tugas akhir.

4. Bagi penulis

Mempublikasikan ilmu yang telah di peroleh selama kuliah yang berbentuk karya nyata dan analisa yang di harapkan berguna untuk masyarakat.

\section{METODE PENELITIAN}

\section{Bahan}

Bahan - bahan yang di siapkan dalam melakukan penelitian ini yaitu :

1. Toolset

Toolset terdiri dari kunci pas ring $8-24 \mathrm{~cm}$, obeng + , obeng -, dan kunci inggris.

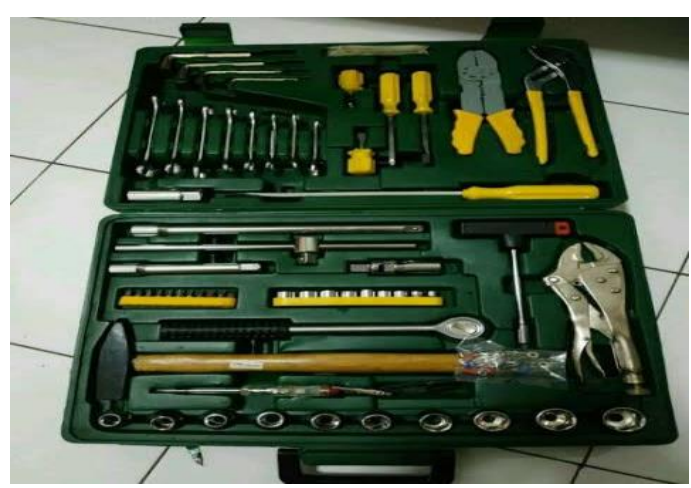

Gambar 1. Toolset

\section{Rpm Counter}

Rpm counter adalah alat yang digunakan untuk mengukur putaran yang dihasilkan mesin.

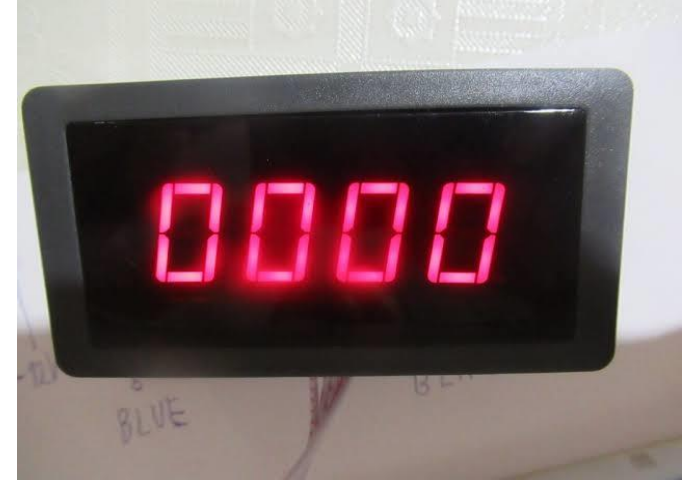

3. Chasis Dynamometer

Gambar 2. Rpm Counter

Chasis dynamometer adalah alat yang digunakan untuk mengukur torsi yang dihasilkan oleh mesin 


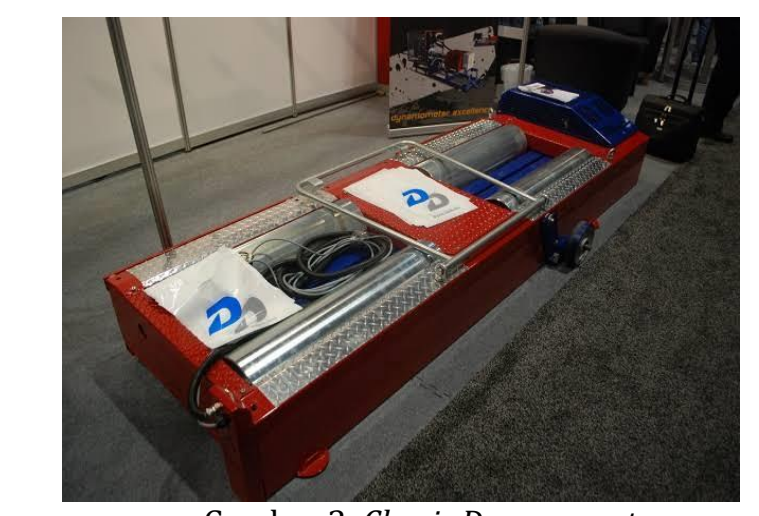

4. Stopwatch

Gambar 3. Chasis Dynamometer

Stopwatch digunakan sebagai alat bantu dalam menghitung konsumsi bahan bakar pada saat pengujian

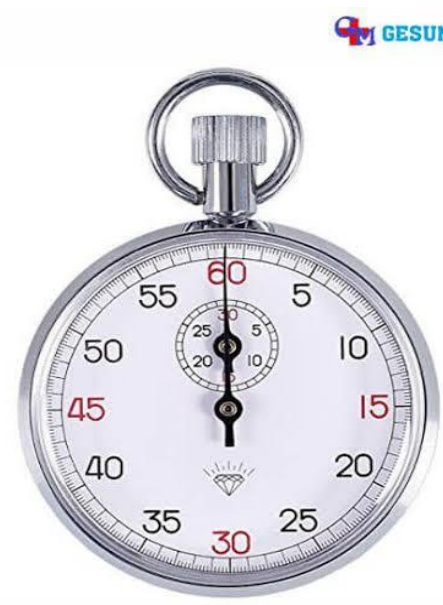

Gambar 4. Stopwatch

\section{Blower}

Blower adalah alat yang digunakan untuk mendinginkan mesin sewaktu pergantian pengujian.

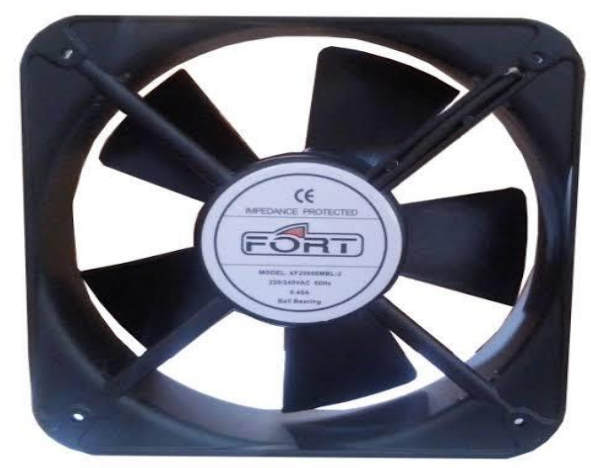

Gambar 5. Blower

\section{Fuel Meter}

Fuel meter digunakan untuk menghitung kebutuhan bahan bakar minyak dalam satuan waktu.
Bahan bakar menggunakan campuran Pertamax dan Methanol

Pertamax:Methanol

$70: 30$

$60: 40$

$50: 50$

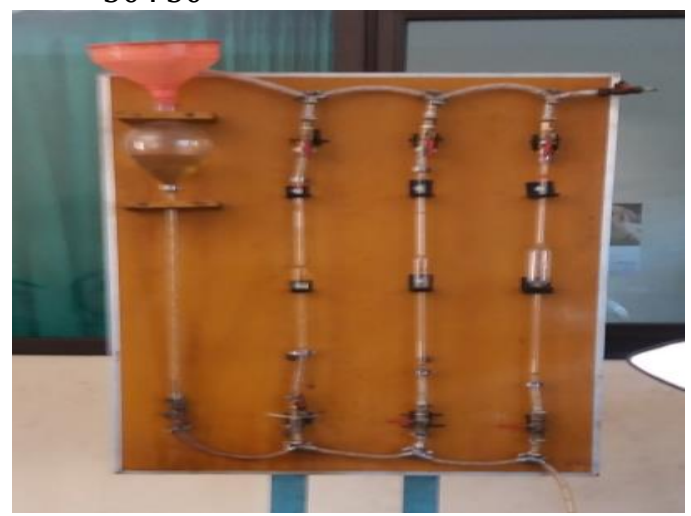

Gambar 6. Fuel Meter

\section{Exhaust Gas Anlyer}

Exhaust gas anlyzer adalah alat yang digunakan untuk mengukur kadar polutan gas buang yang merupakan hsail dari proses pembakaran mesin.

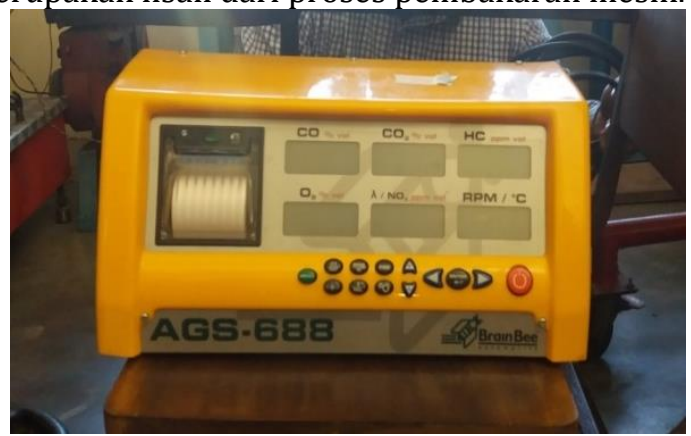

Gambar 7. Exhaust Gas Anlyer

8. Sepeda motor Honda Megapro 160 cc Tahun 2008.

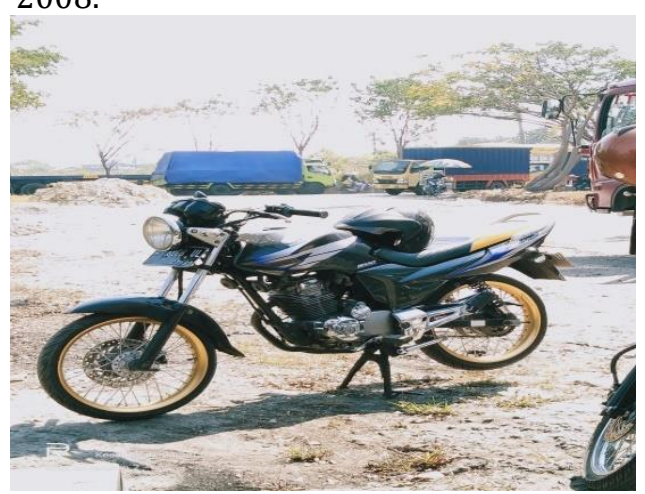

Gambar 8. Sepeda motor Honda Megapro 160 cc Tahun 2008

9. Pertamax dan methanol murni $100 \%$. 


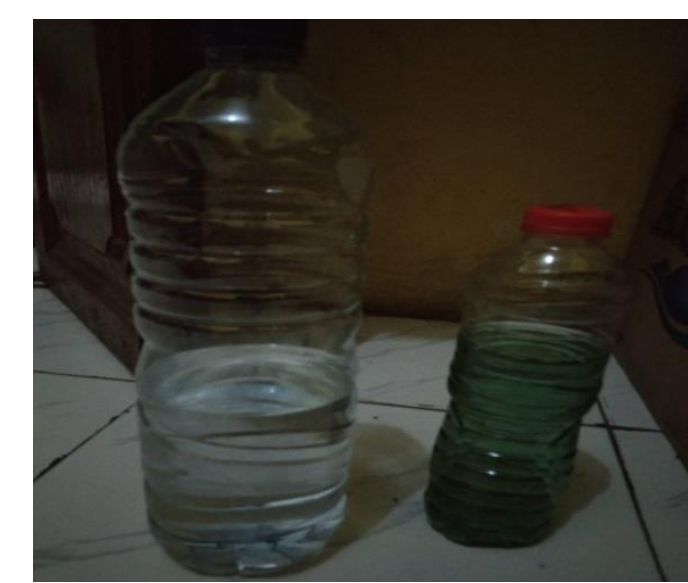

Gambar 9. Pertamax dan methanol murni 100\%.

\subsection{Tempat Penelitian}

Pengambilan data untuk pembuatan skripsi ini dilakukan di Laboratorium Pengujian Performa Mesin Gedung A8 Lt. 1 FT UNESA Jl. Ketintang Surabaya dan bengkel praktek SMK PGRI 1 Sidoarjo.

Tempat ini dipilih karena peralatan sudah cukup lengkap dan memadai serta lebih efisien waktu untuk melakukan penelitian ini.

\subsection{Obyek Penelitian}

Adapun obyek penelitian yang digunakan dalam penelitian ini adalah sepeda motor Honda Megapro 160cc Tahun 2008.

Sepeda motor merupakan kendaraan bermotor yang perkembanganya sangat pesat penggunaanya karena harga yang relative murah dan pengoperasian yang mudah Honda Megapro merupakan sepeda motor 4 langkah produk Honda yang menggunakan bahan bakar bensin. Motor 4 langkah adalah motor yang dalam satu siklus kerjanya memerlukan dua kali putaran poros engkol dan empat kali gerakan torak.

\subsection{Metode}

Siapkan pertamax dan methanol untuk di campurkan ke dalam botol bekas, siapkan kedua bahan tersebut untuk di blanding- $B$ dengan variasi B100, B70, B60, B50.

Ada beberapa hal yang saya teliti yaitu:

1. Mencari data daya, torsi motor menggunakan dynotest.

2. Mencari data konsumsi bahan bakar.

3. Mencari data emisi gas buang menggunakan gas anlyzer.

Langkah-langkah cara mencari data daya, torsi pada dynotest :

1. Menyiapkan kendaraan, bahan yang akan digunakan.

2. Selang yang ditangki kendaraan yang menuju ke karburator dilepas dan sambungkan ke selang dari fuel meter.

3. Mengisi gelas ukur pada fuel meter dengan pertamax secukupnya
4. Menyiapkan chassis dynamometer dan memastikan kondisi sesuai prosedur.

5. Memasang tali pengikat pada kendaraan.

6. Pasang inductive pickup sensor ke kabel koil.

7. Hidupkan komputer, Pilih program sport dyno 33 kemudian Pilih menu Options kemudian pilih configuration dan start motor.

8. Naikkan posisi gigi persneling secara bertahap sampai pada gigi 5 stabilkan putaran mesin pada $3000 \mathrm{rpm}$, lalu tekan tombol switch computer data acquisition satu kali.

9. Naikkan putaran mesin hingga mencapai $10.000 \mathrm{rpm}$ (perubahan putaran mesin dapat dilihat pada tachometer yang terdapat pada layar monitor), kemudian tekan tombol switch computer data acquisition untuk pengambilan data.

10. Pengambilan data pada tingkat putaran 3000 sampai $10.000 \mathrm{rpm}$ dengan rentang $500 \mathrm{rpm}$, data akan tersimpan di PC.

11. Putaran mesin diturunkan secara perlahan.

12. Mesin dan blower dimatikan.

Langkah-langkah cara mencari data konsumsi bahan bakar :

1. Kosongkan bahan bakar pada karburator.

2. Tancapkan selang bahan bakar fuel meter ke karburator.

3. Isi gelas ukur pada fuel meter dengan bahan bakar secukupnya.

4. Start mesin sepeda motor atur pada putaran stabil untuk tiap pengambilan data putaran mesin (2000-10000) dengan rentan Rpm 500'

5. Start mesin sepeda motor atur pada putaran stabil untuk tiap pengambilan data putaran mesin (2000-10000) dengan rentan Rpm 500.

6. Untuk mengkhiri percobaan ini, matikan mesin.

Langkah-langkah cara mencari data emisi gas buang

1. Pengecekan pipa gas buang (tidak terdapat kebocoran).

2. Menyiapkan alat ukur uji emisi kendaraan sesuai standar ISO 3930/OIML R-99.

3. Memberi majun pada sambungan dan lubang pada knalpot agar tidak ada pemasukan udara pada sistem pembuangan.

4. Melakukan kalibrasi exhaust gas analyzer.

5. Menghidupkan mesin dan menjaga posisi temperatur mesin $60^{\circ} \mathrm{C}$.

6. Gigi transmisi pada posisi netral.

7. Memasukkan probe alat uji ke pipa gas buang sedalam $30 \mathrm{~cm}$ lalu tunggu 20 detik untuk pengambilan data konsentrasi gas $\mathrm{CO}$ dan $\mathrm{CO} 2$ dalam satuan persen (\% vol), dan HC dalam satuan ppm yang terukur pada alat uji.

8. Mencetak atau print hasil uji.

9. Melakukan percobaan untuk kelompok pemakaian campuran bahan bakar pertamax dan Methanol. 
10.Putaran mesin diturunkan secara perlahan sampai putaran idle, dan untuk sesaat mesin dibiarkan pada putaran idle.

11. Mesin dan Blower dimatikan.

\section{HASIL DAN PEMBAHASAN}

\subsection{Hasil Pengujian}

Data yang didapat dari eksperimen berupa hasil data daya dan torsi dari mesin sepedah motor yg telah diuji pada dynamometer dan gas analizer, kemudian diolah lebih lanjut menjadi gas sisa pembuangan dan daya. Data yang diperoleh adalah sebagai berikut :

1. Daya dalam satuan HP

2. Putaran dalam satuan RPM

3. Torsi dalam satuan Newton meter (Nm)

4. Emisi gas buang.

Data hasil penelitian dicatat pada lembar observasi dan pengujian kemudian di tabulasikan pada tabel. Setelah semua data terkumpul baru dilakukan perhitungan dan pengolahan data untuk menentukan jenis variasi campuran bahan bakar yang bagus.

\subsection{Data Daya dan Torsi Motor}

Perbandingan torsi dan daya variasi bahan bakar Pertamax dengan Methanol.

Tabel 1. Hasil Torsi Motor

\begin{tabular}{|c|c|c|c|c|c|}
\hline \multirow{2}{*}{ No } & \multirow{2}{*}{ Rpm } & \multicolumn{5}{|c|}{ TORSI Nm } \\
\cline { 3 - 6 } & B100 & B70 & B60 & B50 \\
\hline 1 & 9203 & 6.79 & & & \\
\hline 2 & 9158 & & 7.29 & & \\
\hline 3 & 9532 & & & 7.31 & \\
\hline 4 & 9838 & & & & 7.31 \\
\hline
\end{tabular}

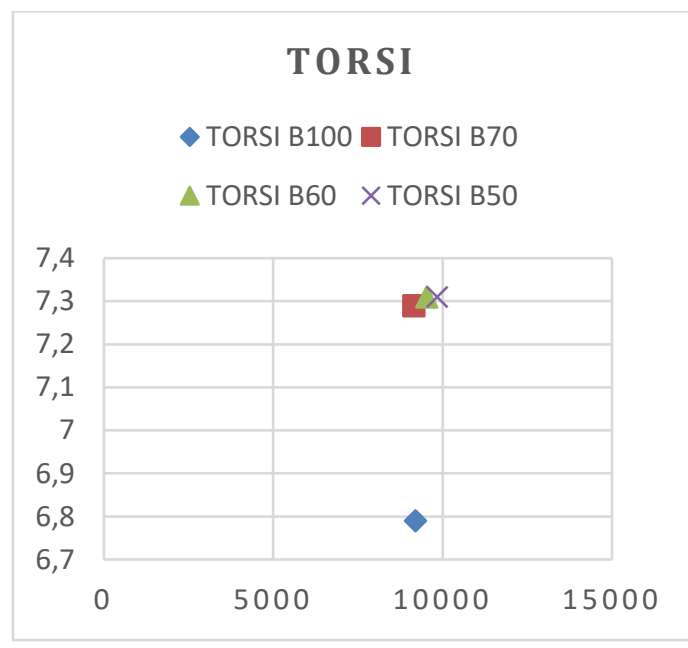

Gambar 1. Grafik Torsi Motor

Tabel 2. Hasil Daya Motor

\begin{tabular}{|c|c|c|c|c|c|}
\hline \multirow{2}{*}{ No } & Rpm & B100 & B70 & B60 & B50 \\
\cline { 3 - 6 } & 11305 & 9.7 & & & \\
\hline 2 & 12451 & & 11 & & \\
\hline 3 & 12448 & & & 11.3 & \\
\hline 4 & 12383 & & & & 11.7 \\
\hline
\end{tabular}

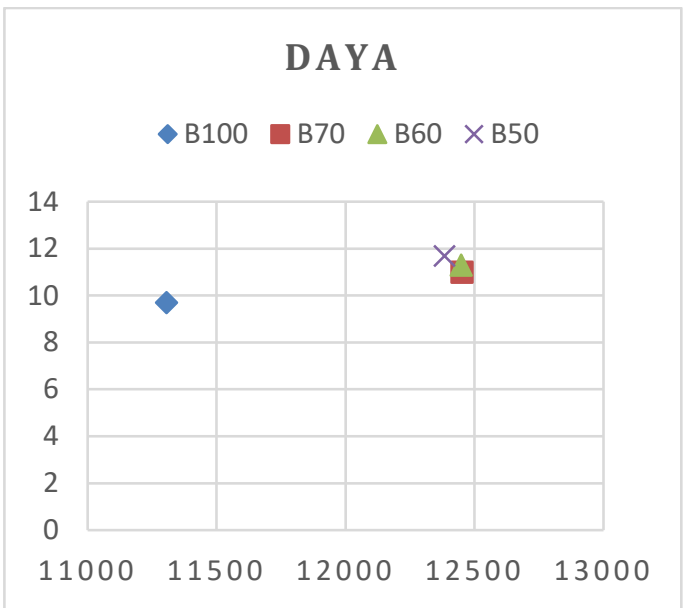

Gambar 2. Grafik Daya Motor

Berdasarkan hasil grafik pengujian diatas didapatkan perbedaan torsi antara variasi bahan bakar Pertamax dengan Methanol (blending-B) B100, B70, B60, B50. Torsi yang menggunakan variasi bahan bakar B50\% pada putaran 9838 yaitu $7.31 \mathrm{Nm}$ cenderung lebih tinggi dari pada torsi yang menggunakan variasi bahan bakar B100, B70, B60, sedangkan variasi bahan bakar Pertamax dengan Methanol (blending-B) 100 pada putaran $9203 \mathrm{rpm}$ yaitu $6.79 \mathrm{Nm}$, variasi bahan bakar B70 pada putaran $9158 \mathrm{rpm}$ yaitu $7.29 \mathrm{Nm}$ dan untuk variasi bahan bakar B60 pada putaran 9532 rpm yaitu 7.31 Nm.

3.3 Perbandingan konsumsi bahan bakar pertamax dengan methanol B100, B70, B60, B50.

Untuk mendapatkan nilai konsumsi bahan bakar dapat dipergunakan rumus sebagai berikut: $\mathrm{Fc}=\frac{b}{t} \cdot \gamma f \cdot \frac{3600}{1000} \cdot \frac{\mathrm{kg}}{\mathrm{jam}}$

Keterangan $: \mathrm{Fc}=$ Konsumsi bahan bakar $[\mathrm{kg} / \mathrm{jam}] \mathrm{b}=$ Volume bahan bakar selama t detik [ $\mathrm{ml}$ ]

$\mathrm{t}=$ Waktu untuk menghabiskan bahan bakar sebanyak $10 \mathrm{ml}$ [det]

४f = Berat spesifikasi bahan bakar [ kp/lt ]

Dari data hasil pengujian didapatkan sebagai berikut :

a. $\mathrm{b}: 10 \mathrm{ml}$

b. if : $0,715 \mathrm{~s} / \mathrm{d} \quad 0,780 \mathrm{~kg} / \mathrm{lt}$ (untuk bahan Pertamax dan Mehanol)

$$
\text { c. } t \quad: 120,18 \mathrm{det}
$$

Maka : $\quad \mathrm{Fc}=\frac{10}{120,18} \cdot 0,750 \cdot \frac{3600}{1000} \cdot \frac{\mathrm{kg}}{\mathrm{jam}}$ 


$$
\mathrm{Fc}=0,21 \frac{\mathrm{kg}}{\mathrm{jam}}
$$

Dengan metode yang sama dengan perhitungan diatas maka didapatkan nilai konsumsi bahan bakar untuk masing-masing bahan bakar yaitu sebagaimana tabel dibawah ini :

Tabel 3. Hasil Konsumsi Bahan Bakar

\begin{tabular}{|c|c|c|c|c|}
\hline \multirow{2}{*}{ RPM } & \multicolumn{4}{|c}{ Konsumsi Bahan Bakar (Fc } \\
\cline { 2 - 5 } & B100 & B70 & B60 & B50 \\
\hline 2000 & 0,276 & 0,264 & 0,240 & 0,229 \\
\hline 2500 & 0,281 & 0,273 & 0,254 & 0,242 \\
\hline 3000 & 0,284 & 0,282 & 0,269 & 0,258 \\
\hline 3500 & 0,302 & 0,294 & 0,277 & 0,265 \\
\hline 4000 & 0,328 & 0,315 & 0,292 & 0,271 \\
\hline 4500 & 0,347 & 0,328 & 0,308 & 0,293 \\
\hline 5000 & 0,369 & 0,338 & 0,328 & 0,316 \\
\hline 5500 & 0,396 & 0,358 & 0,348 & 0,337 \\
\hline 6000 & 0,440 & 0,385 & 0,369 & 0,345 \\
\hline 6500 & 0,487 & 0,432 & 0,393 & 0,370 \\
\hline 7000 & 0,534 & 0,475 & 0,417 & 0,395 \\
\hline 7500 & 0,616 & 0,536 & 0,468 & 0,455 \\
\hline 8000 & 0,664 & 0,604 & 0,537 & 0,516 \\
\hline 8500 & 0,734 & 0,647 & 0,576 & 0,558 \\
\hline 9000 & 0,807 & 0,712 & 0,664 & 0,646 \\
\hline 9500 & 0,837 & 0,786 & 0,758 & 0,659 \\
\hline 10000 & 0,885 & 0,853 & 0,786 & 0,682 \\
\hline Rata- & & & & \\
Rata Fc & 0,464 & 0,463 & 0,425 & 0,402 \\
\hline
\end{tabular}

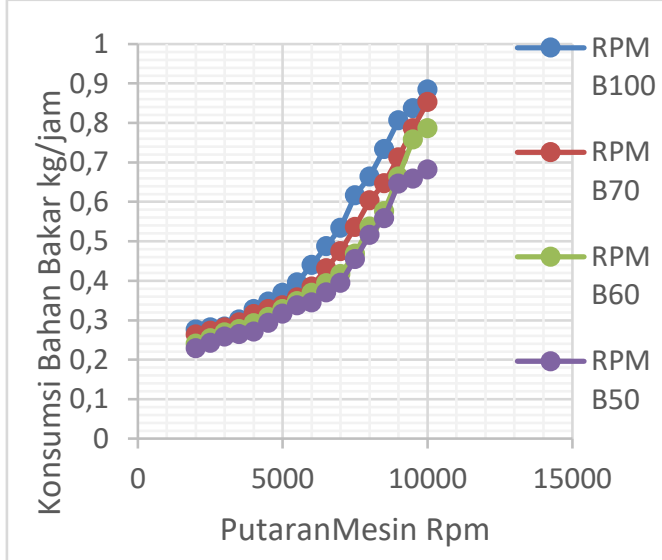

Gambar 3. Grafik Konsumsi Bahan Bakar

Berdasarkan tabel menunjukkan bahwa ada perbedaan hasil perhitungan Fc rata-rata antara bahan bakar Pertamax dengan Mehanol (blendingB) B100, B70, B60, dan B50. Pada sepeda motor Honda Megapro 160 cc yang menggunakan bahan bakar B100 membutuhkan rata-rata Fc 0.464 $\mathrm{Kg} / \mathrm{jam}$, Bahan bakar B70\% membutuhkan ratarata $\mathrm{Fc} 0.463 \mathrm{Kg} / \mathrm{jam}$, Bahan bakar B60 membutuhkan rata-rata $\mathrm{Fc} 0.425 \mathrm{Kg} / \mathrm{jam}$, dan Bahan bakar B50 membutuhkan rata-rata Fc 0.402 $\mathrm{Kg} / \mathrm{jam}$. Berdasarkan data tersebut penggunaan Bahan bakar B50 lebih irit dibandingkan dengan variasi B100, B70, dan B60.

3.4Perbandingan analisa emisi gas buang pertamax dengan methanol (blending-B)

Pada pengujiangas sisa pembakaran menggunakan variasi bahan bakar Pertamax dengan Methanol (blending-B), elemen gas buang yang di teliti adalah presentase volume gas $\mathrm{CO}, \mathrm{CO} 2$, 02 dan HC. Emisi gas buang adalah gas sisa hasil pembakaran bahan bakar di dalam mesin pembakaran dalam dan pembakaran luar, yang di buang melalui saluran pembuangan mesin. Apabila suatu senyawa hidrokarbon terbakar sempurna maka hasil reaksi pembakaran tersebut adalah karbondioksida (CO2) dan air (H2O). Sama seperti gas C02, konsentrasi HC dalam gas buang dipengaruhi oleh proses pembakaran dan AFR. Emisi gas HC akan tinggi apabila terjadi pembakaran yang kurang baik dan AFR terlalu kaya. Tabel 4. Hasil Data Analisa Gas Buang

\begin{tabular}{|c|c|c|c|c|c|}
\hline & Satuan & B100 & B70 & B60 & B50 \\
\hline $\mathrm{CO}$ & $(\% \mathrm{Vol})$ & 6.51 & 6.95 & 6.6 & 6.43 \\
\hline $\mathrm{CO}_{2}$ & $(\% \mathrm{Vol})$ & 3.6 & 3.9 & 4.3 & 4.9 \\
\hline $\mathrm{HC}$ & $(\% \mathrm{Vol})$ & 1822 & 1314 & 9613 & 7446 \\
\hline $\mathrm{O}_{2}$ & $(\mathrm{ppmVol})$ & 9.24 & 8.62 & 8.6 & 7.92 \\
\hline $\mathrm{Nox}$ & $(\% \mathrm{Vol})$ & 0 & 0 & 0 & 0 \\
\hline Lambda & & 1.145 & 1.134 & 1.175 & 1.151 \\
\hline
\end{tabular}

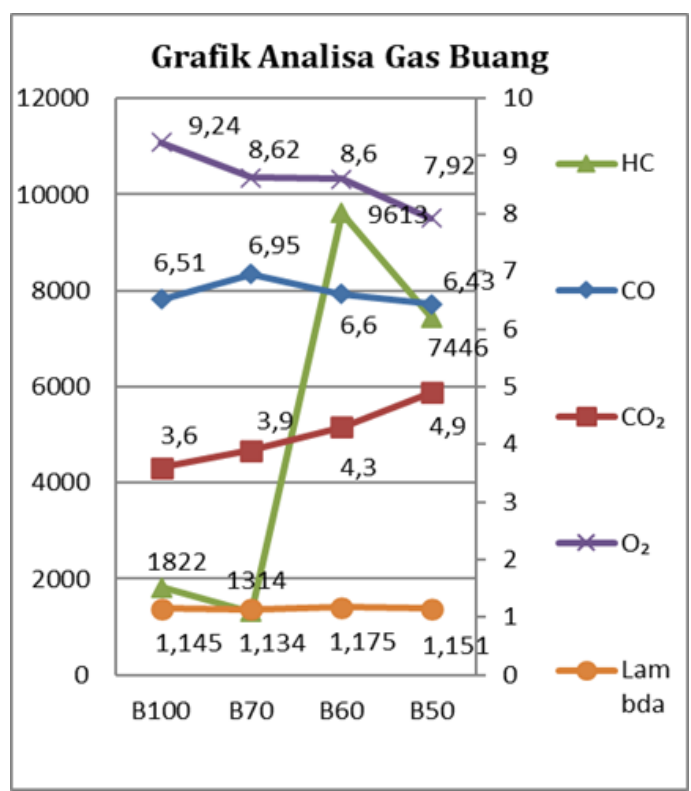

Gambar 4. Grafik Analisa Gas Buang.

\section{PENUTUP}




\subsection{Kesimpulan}

Berdasarkan Analisa hasil pengujian dan pembahasan 4 variasi bahan bakar Pertamax dengan Methanol (blending-B) B100, B70, B60, dan B50 pada sepeda motor Honda Megapro 160 CC tahun 2008, dapat disimpulkan sebagai berikut :

1. Dalam hasil uji Torsi maksimum dapat disimpulkan bahwa adanya perbedaan torsi antara yang menggunakan campuran bahan bakar Pertamax dan Methanol B100, B70, B60, dan B50. Dari data diatas, torsi yang menggunakan bahan bakar B100 cenderung lebih tinggi sedikit dibandingkan dengan torsi yang menggunakan bahan bakar B70, B60, dan B50, sedangkan variasi campuran terbaik adalah B70. Torsi maksimum terjadi pada pada putaran $9396 \mathrm{rpm}$ yaitu $7.21 \mathrm{Nm}$, sedngkan torsi maksimum untuk B60 terjadi pada putaran $9532 \mathrm{rpm}$ yaitu $7.31 \mathrm{Nm}$ dan untuk B50 terjadi pada putaran $9838 \mathrm{rpm}$ yaitu 7.31 $\mathrm{Nm}$.

2. Dalam hasil uji Daya maksimum disimpulkan bahwa adanya perbedaan torsi antara yang menggunakan campuran bahan bakar Pertamax dan Methanol B100, B70, B60, dan B50. Dari data diatas torsi yang menggunakan bahan bakar B100 cenderung lebih tinggi sedikit dibandingkan dengan torsi yang menggunakan bahan bakar B70, B60, dan B50, sedangkan variasi campuran terbaik adalah B70. Daya maksimum terjadi pada pada putaran $12451 \mathrm{rpm}$ yaitu $11 \mathrm{Hp}$, sedngkan torsi maksimum untuk B60 terjadi pada putaran $12891 \mathrm{rpm}$ yaitu $11.2 \mathrm{Hp}$ dan untuk B50 terjadi pada putaran $12652 \mathrm{rpm}$ yaitu 11.5 Hp.

3. Di dalam data uji konsumsi bahan bakar menunjukkan bahwa ada perbedaan hasil perhitungan Fc rata-rata antara campuran bahan bakar Pertamax dan Methanol B100, B70, B60, dan B50. Pada sepeda motor Honda Megapro 160 cc yang menggunakan bahan bakar B100 membutuhkan rata-rata Fc 0,464 $\mathrm{Kg} / \mathrm{jam}$, Bahan bakar B70 membutuhkan ratarata Fc $0,463 \mathrm{Kg} / \mathrm{jam}$, Bahan bakar M40 membutuhkan rata-rata Fc $0,425 \mathrm{Kg} / \mathrm{jam}$, dan Bahan bakar B50 membutuhkan rata-rata Fc $0,402 \mathrm{Kg} / \mathrm{jam}$. Berdasarkan data tersebut penggunaan Bahan bakar B50 lebih irit dibandingkan dengan variasi campuran B100, B70, dan B60.

4. Dalam pengujian Analisa gas buang menunjukkan bahwa adanya perbedaan hasil Analisa gas buang rata-rata antara campuran bahan bakar Pertamax dan Methanol B100, B70, B60, dan B50.Sepeda motor Honda Megapro 160 CC Yang Menggunakan M0 menghasilkan rata-rata kadar HC 1822 (\%vol), dan kadar CO2 3.6 (\%VOL), Bahan bakar M30 menghasilkan rata-rata kadar $\mathrm{HC}$ 1314(\%vol)dan kadar CO2 3.9 (\%VOL), Bahan bakar M40 menghasilkan rata-rata kadar HC 9613(\%vol), dan kadar CO2 4.3 (\%VOL), Bahan bakar B50 menghasilkan rata-rata kadar HC 7446(\%vol), dan kadar CO2 4.9 (\%VOL). Berdasarkan data tersebut dapat disimpulkan, bahwa B70 Pembakarannya yang paling sempurna, terjadi proses pembakaran yang paling baik hasilnya dibandingkan dengan uji pemakaran variasi campuran B60, dan B50.

5. Dari pengujian yang variasi campuran bahan bakar B70, dapat menghasilkan unjuk kinerja yang paling baik, pada sepeda motor Honda Megapro 160 CC Tahun 2008.

\subsection{Saran}

Adapun saran yang dapat diberikan sebagai upaya untuk perbaikan pada masa/tahun yang akan datang sebagai berikut:

1. Untuk penelitian yang lebih lanjut bisa dilakukan dengan cara yang sama, akan tetapi dengan menggunakan perbandingan bahan bakar yang campurannya lebih bervariasi.

2. Sebelum melakukan uji atau penelitian, kondisi sepeda motor harus dalam keadaan atau kondisi yang standart (setelah d tune up).

\section{DAFTAR PUSTAKA}

Afifah, Y. N. (2016). ALIRAN TAK TUNAK FLUIDA NANO MAGNETOHIDRODINAMIK ( MHD) YANG MELEWATI BOLA.

Afifah, Y. N. (2019). (2019). Analysis of Unsteady Magneto Hydro Dynamic ( MHD) Nano Fluid Flow Past A Sliced Sphere Analysis of Unsteady Magneto Hydro Dynamic ( MHD ) Nano Fluid Flow Past A Sliced Sphere. IOP Conference Series: Materials Science and Engineering, 494, 012033. https://doi.org/10.1088/1757899X/494/1/012033

Afifah, Y. N., \& Putra, B. C. (2018). Model Matematika Aliran Tak Tunak Pada Nano Fluid Melewati Bola Teriris Dengan Pengaruh Medan Magnet. Teknika: Engineering and Sains Journal, 2(2), 119-124.

Agrariksa, F. A., Susilo, B., \& Nugroho, W. A. (2013). Uji Performansi Motor bakar Bensin ( On Chassis) Menggunakan Campuran Premium dan Refbacks.

Ambarita, H. (2017). PENGUJIAN MESIN DIESEL YANG DIMODIFIKASI MENJADI BERBAHAN BAKAN GAS LPG. Turbo: Jurnal Program Studi Teknik Mesin. https://doi.org/10.24127/trb.v6i2.603

Kimia, I. B. (n.d.). METANOL. (5). 
Menu, M. (2014). Pengaruh Penggunaan dan Perhitungan Efisiensi Bahan Bakar Premium dan Pertamax Terhadap Unjuk Kerja Motor Bakar Bensin Refbacks.

Mulyono, S., Gunawan, G., \& Maryanti, B. (2014). Pengaruh Penggunaan dan Perhitungan Efisiensi Bahan Bakar Premium dan Pertamax Terhadap Unjuk Kerja Motor Bakar Bensin. JTT (Jurnal Teknologi Terpadu). https://doi.org/10.32487/jtt.v2i1.38

Ramdani, S. (2017). ANALISIS PENGARUH VARIASI CDI TERHADAP PERFORMA DAN KONSUMSI BAHAN BAKAR HONDA VARIO 110cc. Jurnal Teknik Mesin. https://doi.org/10.22441/jtm.v4i3.1271

Romani, F. A. (1990). METANOL. Revista Brasileira de Oftalmologia.

Winarno, J. (2011). Studi Eksperimental Pengaruh Penambahan Bioetanol Pada Bahan Bakar Pertamax Terhadap Unjuk Kerja Motor Bensin. Jurnal Teknik.

Yunita Nur Afifah, MNH Qomarudin, \& Imamatul Ummah. (2020). Optimal Control Model Pemanenan Prey-Predator di Area Konservasi Ikan. Buana Matematika: Jurnal Ilmiah Matematika Dan Pendidikan Matematika, 10(1), 1-16. https://doi.org/10.36456/buanamatematik a.v10i1.2410 